\title{
十二指腸蟲ノ發育二關スル實驗的研究
}

人十二指腸蟲 Anchylostoma duodenale, Dubini.

\author{
仔蟲キ仔犬二經膚感染後ソノ肺臟ヨリ得タル \\ 幼蟲キ更二家兔二興へタル場合ノ發育 \\ 狀態二就テ(第四編)
}

東京帝国大學傳染病研究所附島醫院研究室(主任宮川数投)

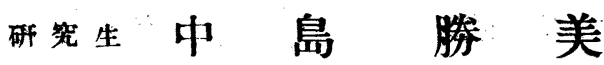

目次

緒 論

第一賽驗材料及ビ筫驗方法

第一章 實领材料

第二章 筫驗方法

第二 實驗成綪

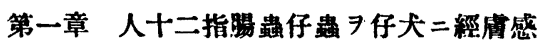
染後ソノ肺䑏ヨ、旦得タル幼蟲 7 家 兔二經口的二與へタル場合．家鬼 體內二於ヶル䇋青狀態

第二章 對照實験

第一節 人十二指腸蟲仔蟲 卜肺嘰乳蝴二テ處置セル後家兔 二興へタル埸合二於々ル蒿狀
熊

第二節 人十二指腸蟲仔䖵 7 人體肺腈孚 绪二テ處置セル後家兔二興へタ ル堨合二於ヶル發育狀㮩

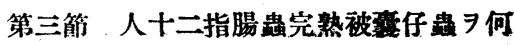
等, 處置 7 施サズ家兔二與へシ 場合，䇣育狀照

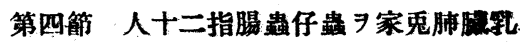
缡二テ虑置七ル後家鬼二興人 ル場合二於ヶル镸育狀態

\section{第三 總括的所見}

結 論

文 獻

附 㖥

\section{粕 諗}

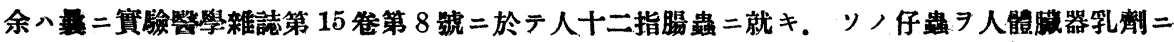
テー定期間操作セル後之 7 人體以外，家兔二興フル時八當該動物體內二於テモ可成り著明ナル

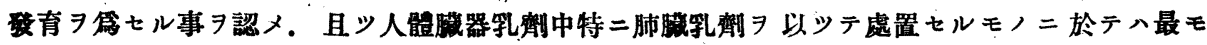

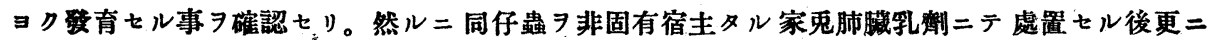

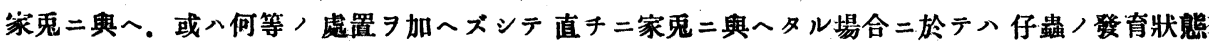
八何レモ何等特二育セリト思ハル、所見习認メ能ヘザリシ事ノ知見习述ベ置キタリ。

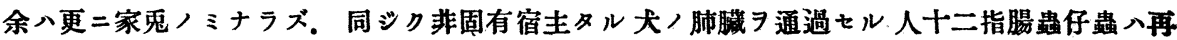

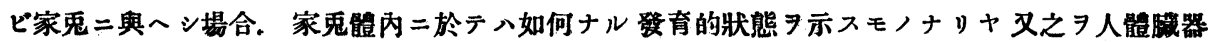

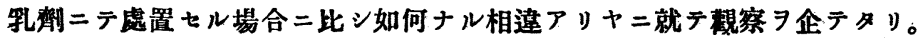

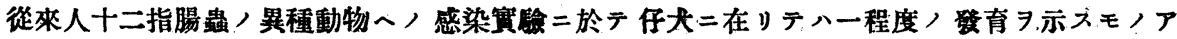




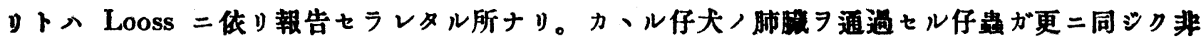

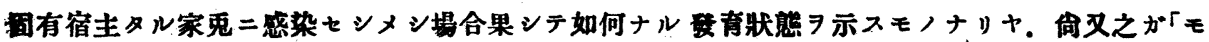

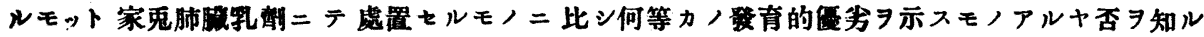

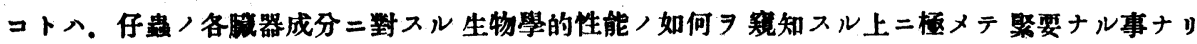
ト信シ本賽鍳习遂行セり。

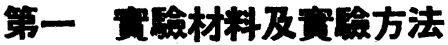

\section{第一章 容踰材料}

第一編二於亏記載七ルト同樣人十二指腸量 Anchylostoma duodenale, Dbuini， /

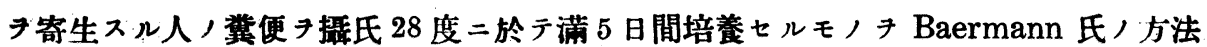

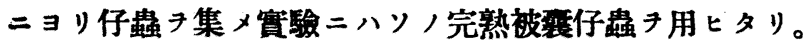

\section{第二章 蒉羷方法}

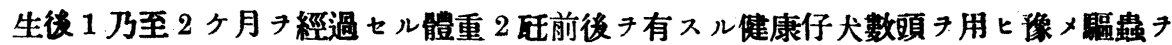

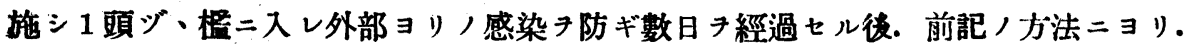

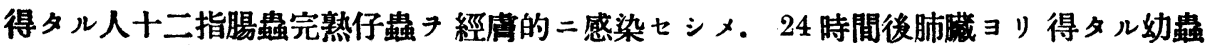

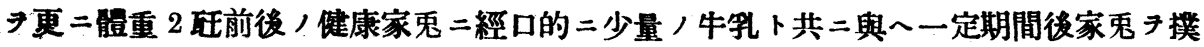

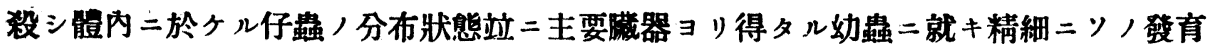
狀態き检セり。

\section{第二 宣珨成綪}

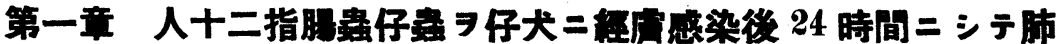

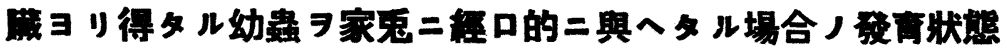

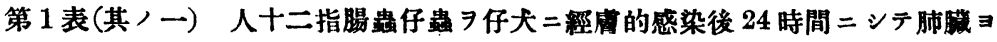

\begin{tabular}{|c|c|c|c|c|c|c|c|c|}
\hline \multicolumn{2}{|l|}{ 家 } & \multirow{2}{*}{$\begin{array}{l}\text { 感經 } \\
\text { 染過 } \\
\text { 日 } \\
\text { 後數 }\end{array}$} & \multirow{2}{*}{ 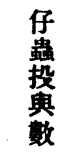 } & \multicolumn{2}{|c|}{ 檢 出 } & \multicolumn{2}{|l|}{ 肺 } & 臟 \\
\hline $\begin{array}{l}\text { 香 } \\
\text { 號 }\end{array}$ & $\begin{array}{l}\text { 體 } \\
\text { 重 } \\
\text { 觟 }\end{array}$ & & & $\begin{array}{l}\text { 總 } \\
\text { 數 }\end{array}$ & $\begin{array}{l}\text { 投對 } \\
\text { 塞不 } \\
\text { 數 } \\
=\%\end{array}$ & $\begin{array}{l}\text { 檢 } \\
\text { 出 } \\
\text { 數 }\end{array}$ & $\begin{array}{l}\text { 投對 } \\
\text { 霓衣 } \\
=\% \\
=\%\end{array}$ & 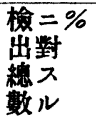 \\
\hline 1 & 1.750 & 3日 & 3000 & 366 & 12.20 & 180 & 6.0 & 49.18 \\
\hline 2 & 1.800 & 5 日 & 1000 & 118 & 11.80 & 30 & 3.0 & 25.42 \\
\hline 3 & 1.800 & 7日 & 4500 & 390 & 8.66 & 42 & 0.93 & 10.76 \\
\hline 4 & 1.850 & 9日 & 1600 & 67 & 4.18 & 6 & 0.37 & 8.95 \\
\hline 5 & 1.800 & 11日 & 4000 & 402 & 10.05 & 23 & 0.57 & 5.72 \\
\hline
\end{tabular}




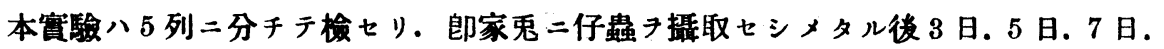
9 日. 11 日分チ夫々行へリ。

仔贵，體内分布狀態八第 1 表 (其ノ一) 二示ス如ク感染後初メ5 日頃迄八肺臟二集 ル仔䖵ハ多數ナレドモ。ソノ後ハ却ッテ氣管. 胃. 腸二見出サル、仔䖵數多シ。

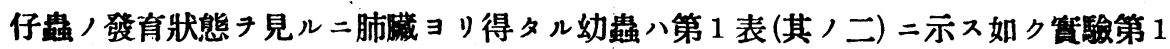
例 $コ$ 第 5 例二至ル汽何レモ著明キナセルモノナシ。（表中各時期ニ於ケル仔蟲）體

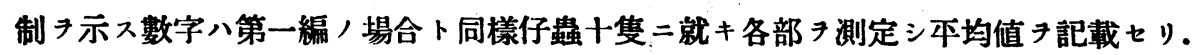
十隻以下, 場合ハソ, 得タル仔蟲全部キ測定シ其ノ本均值キ揭ゲタリ。以下各實驗成 績表二就テモ叉全部之二準ズルモノナリ)。感染媵 11 日キ經過セルモノニ於テモ口襄 原基尹形成セルモノナク一般二體內顆粒堿少セルモノ多シ。

氣管及ビ喉頭ヨリ得タル幼蟲二就テ見ル二第 1 表 (其ノ三)二示ス如ク前記肺臟ヨリ ノモノニ比シ大差ナク. 何レモ著明ノ撜有ナシ。唯實驗第 3 例二於テ體長. 生殖器原

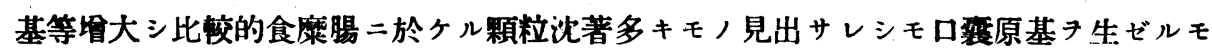
ノタ認ムルコト能ハザリキ。

胃ヨリ得タル幼蟲二就テ見ル時八第 1 表 (其，四)二示ス如ク前述，肺瀻氣管及ビ喉 頭ヨリ得タル幼蟲二比シ少シク發有ヨ示スモ, 多ク見出サレ賽驗第 4 例二於テ八體 長. 體幅生殖器原基等何レモ增大シ，初期/口襄原基丹形成セルモノアリ．而シテ. カ、ルモノ二於テモ少ホ未ダ第 3 回脫皮終了七ズ. 其他ノモノニ於テハ認ム心゙キ著 明ノ發有丹示スモノナカリキ。

小腸ヨリノモノ八第 1 表(其ノ五)二示ス如ク胃二於テ見出サレタル蟲體ヨリ更ニヨ ク發有セルモノタ認メタリ。即千賽䁩第 4 例二於テ一匹ハ口襄原基形成卜共二第 3 回 脫皮き第シ食糜腸二於ケル顆粒ハ增加シ腸細胞等モ比較的明暸トナり發育進メルモ， アリタリ．他ノモノ八何レモ著明，發有ナク感染後 11 日尹經過セル實驗第 5 例二於 リ得タル幼䖵 $コ$ 再ビ家鬼二經口的二興へシ場合其，體內ニ於ヶル幼蛊，分布狀態

\begin{tabular}{|c|c|c|c|c|c|c|c|c|c|c|c|}
\hline \multicolumn{3}{|c|}{ 氣管及ビ喉頭 } & \multicolumn{3}{|c|}{ 胃 } & \multicolumn{2}{|c|}{ 小 } & \multirow{2}{*}{$\begin{array}{c}\text { 腸 } \\
\text { 檢二\% } \\
\text { 出對 } \\
\text { 總ス } \\
\text { 數ル }\end{array}$} & \multicolumn{2}{|c|}{ 大 } & \multirow{2}{*}{ 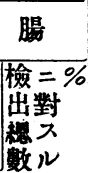 } \\
\hline $\begin{array}{l}\text { 檢 } \\
\text { 出 } \\
\text { 數 }\end{array}$ & $\begin{array}{l}\text { 投對 } \\
\text { 與ス } \\
\text { 數ル } \\
=\%\end{array}$ & 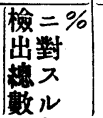 & $\begin{array}{l}\text { 檢 } \\
\text { 欪 } \\
\text { 數 }\end{array}$ & $\begin{array}{l}\text { 投對 } \\
\text { 與ス } \\
\text { 數ル } \\
=\%\end{array}$ & 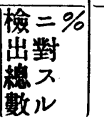 & $\begin{array}{l}\text { 檢 } \\
\text { 欪 } \\
\text { 數 }\end{array}$ & $\begin{array}{l}\text { 投對 } \\
\text { 與不 } \\
\text { 數ル } \\
=\%\end{array}$ & & $\begin{array}{l}\text { 檢 } \\
\text { 出 } \\
\text { 數 }\end{array}$ & $\begin{array}{l}\text { 投對 } \\
\text { 興 } \\
\text { 數ル } \\
=\%\end{array}$ & \\
\hline 91 & 3.03 & 24.86 & 86 & 2.86 & 23.49 & 4 & 0.13 & 1.09 & 5 & 0.16 & 1.36 \\
\hline 21 & 2.1 & 17.79 & 64 & 6.4 & 54.23 & 2 & 0.2 & 1.69 & 1 & 0.1 & 0.84 \\
\hline 30 & 0.66 & 7.69 & 291 & 6.46 & 74.61 & 18 & 0.4 & 4.61 & 9 & 0.2 & 2.30 \\
\hline 40 & 2.50 & 59.70 & 16 & 1.00 & 23.88 & 5 & 0.31 & 7.46 & 0 & 0 & 0 \\
\hline 216 & 5.40 & 53.73 & 149 & 3.72 & 37.06 & 7 & 0.17 & 1.74 & 7 & 0.17 & 1.74 \\
\hline
\end{tabular}




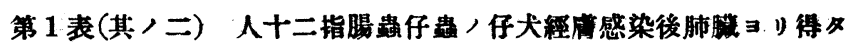

\begin{tabular}{|c|c|c|c|c|c|c|c|}
\hline \multirow{2}{*}{\multicolumn{2}{|c|}{ 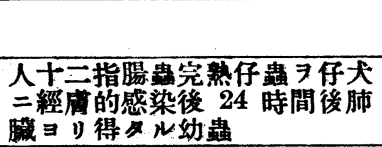 }} & 家鬼番號 & 經過時間 & '體 長 & 體 幅 & 食道長 & 食道球调 \\
\hline & & & & 0.669 & 0.0254 & 0.149 & 0.0159 \\
\hline 肺 & 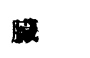 & 1 & 3 日 & 0.680 & 0.0230 & 0.157 & 0.0153 \\
\hline & & 2 & 5 日 & 0.697 & 0.0230 & 0.161 & 0.0153 \\
\hline & & 3 & 7日 & 0.680 & 0.0230 & 0.162 & 0.0153 \\
\hline & & 4 & 9日 & 0.713 & 0.0250 & 0.172 & 0.0168 \\
\hline & & 5 & $11 日$ & 0.680 & 0.0230 & 0.165 & 0.0153 \\
\hline
\end{tabular}

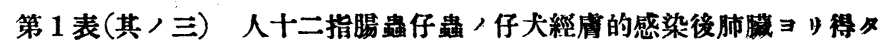

\begin{tabular}{|c|c|c|c|c|c|c|}
\hline & |家鬼番號 $\mid$ & 經過時間 & 體 長 & 體 幅 & 食道長 & 食道球愊 \\
\hline 氣管及ビ喉頭 & 1 & 3日 & 0.713 & 0.0230 & 0.172 & 0.0153 \\
\hline 上 & 2 & 5日 & 0.695 & 0.0230 & 0.165 & 0.0153 \\
\hline 同 上 & 3 & 7 日 & 0.730 & 0.0230 & 0.175 & 0.0153 \\
\hline 同上 & 4 & 9 日 & 0.697 & 0.0238 & 0.168 & 0.0153 \\
\hline 同上 & 5 & 11日 & 0.680 & 0.0230 & 0.176 & 0.0153 \\
\hline
\end{tabular}

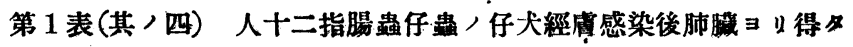

\begin{tabular}{|c|c|c|c|c|c|c|}
\hline & 家鬼番號 & 經過時間 & 體 長 & 體 幅 & 食道長 & 食道幅 \\
\hline 胃 & 1 & 3 日 & 0.710 & 0.0249 & 0.176 & 0.0153 \\
\hline$"$ & 2 & 5日 & 0.680 & 0.0230 & 0.163 & 0.0153 \\
\hline$\cdot$ & 3 & 7日 & 0.705 & 0.0234 & 0.170 & 0.0153 \\
\hline$"$ & 4 & 9日 & $\begin{array}{l}\text { 大0.813 } \\
\text { 小0.713 }\end{array}$ & $\begin{array}{l}0.0268 \\
0.0230\end{array}$ & $\begin{array}{l}0.195 \\
0.172\end{array}$ & $\begin{array}{l}0.0192 \\
0.0153\end{array}$ \\
\hline$"$ & 5 & 11日 & $\begin{array}{l}\text { 大0.763 } \\
\text { 小0.664 }\end{array}$ & $\begin{array}{l}0.0268 \\
0.0226\end{array}$ & $\begin{array}{l}0.184 \\
0.157\end{array}$ & $\begin{array}{l}0.0153 \\
0.0153\end{array}$ \\
\hline
\end{tabular}


ルル幼轟 再ピ家鬼二経口的二舆へ各蔵器ヨリ得タルル幼轟ノ豪育状態

ル幼負 $\ni$ 再ビ家鬼二経口的二與へ各藏器ヨリ得タルル幼轟ノ登育賦態 
テハ僅カニ初期ノロ襄原基ラ形成セルラ認ムルモノアリシモ未ダ第3同脱皮テ爲サ

ズ。禮内穎粒ノ増加其他何レモ登育ラ認ムルモノナカリキ。

大腸ヨリ得タル幼貣二就テハ第1表1其ノ六)二示ス如ク何ルモ著明ノ登育ヨ示スモ ノナク却ツテ膿内榮養穎粒ノ減少セルモノ多カリキ.

以上記載セル如ク人十一指腸轟仔轟 $ᄏ$ 仔犬二感染セシメ其ノ後24時間二於テ肺藏 ヨリ仔轟」躯之テ再ピ塞鬼二與フル時ハ大多藪ハ殁ンド何等認ムベキ登育テ見ザ ルモノナ測上管特二小腸二於テ多襲観セル負艦中僅カニー匹二於テ第3回脱皮

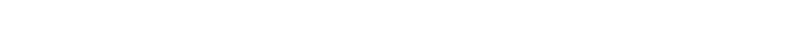
到底暴ゲテ数フルニ足ラズ. 斯クノー如ク仔犬ノ肺藏 通過セシムルコト三ヨリ.人+ 一指腸轟ノ仔負八其ノ有ス遮種首特異姓Rost speci tyラ失ハシムル事能ハザルモ ノナリ。之ヨ余カ襲二行ヒタル入禮藏器乳斉特二肺藏乳剤二テ慮置シテ行へル實験二 比スル時八驚クベキ顯著ナル登育的相建ラ來スモノナルコトラ知ルリ。 


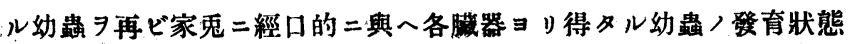

\begin{tabular}{|c|c|c|c|c|c|c|}
\hline $\begin{array}{l}\text { 生殖器 } \\
\text { 原基 }\end{array}$ & $\begin{array}{l}\text { 自胿㥃 } \\
\text { 至尾端 }\end{array}$ & 頭部 /廣 & $\begin{array}{l}\text { 膓先端 } \\
\text { 部，廣 }\end{array}$ & $\begin{array}{l}\text { 灭門部二於 } \\
\text { ケル體幅 }\end{array}$ & $\begin{array}{l}\text { 口襄原基 } \\
\text { ア }\end{array}$ & 第一次ノモノト / 比較 \\
\hline $\begin{array}{l}0.0153 \\
0.0076\end{array}$ & 0.084 & 0.0115 & 0.0115 & 0.0153 & ナ : シ & 何等認ムぶキ發育ナシ \\
\hline $\begin{array}{l}0.0153 \\
0.0076\end{array}$ & 0.084 & 0.0115 & 0.0124 & 0.0153 & ナ シ & 同上 \\
\hline $\begin{array}{l}0.0162 \\
0.0096 \\
0.0153 \\
0.0076\end{array}$ & $\begin{array}{l}0.088 \\
0.084\end{array}$ & $\begin{array}{l}0.0130 \\
0.0115\end{array}$ & $\begin{array}{l}0.0135 \\
0.0115\end{array}$ & $\begin{array}{l}0.0170 \\
0.0153\end{array}$ & $ナ$ & 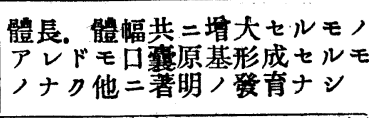 \\
\hline $\begin{array}{l}0.0211 \\
0.0115 \\
0.0153 \\
0.0076 \\
\end{array}$ & 0.080 & 0.0288 & $\begin{array}{l}0.027 .6 \\
0.0115\end{array}$ & $\begin{array}{l}0.0276 \\
0.0153\end{array}$ & $\frac{1}{5}$ & 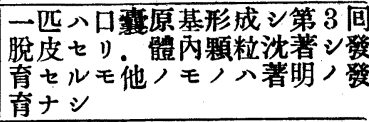 \\
\hline $\begin{array}{l}0.027: 3 \\
0.0115 \\
0.0153 \\
0.0076\end{array}$ & 0.084 & 0.0192 & $\begin{array}{l}0.0192 \\
0.0115\end{array}$ & $\begin{array}{l}0.0192 \\
0.0153\end{array}$ & $\frac{1}{7}$ & 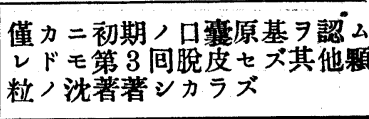 \\
\hline
\end{tabular}

ル幼蟲 $\ni$ 再ビ家鬼二經口的二興へ各臟器ヨリ得タル幼蟲ノ筑育狀態

\begin{tabular}{|c|c|c|c|c|c|c|c|}
\hline 生殖器 & $\begin{array}{l}\text { 自肛門 } \\
\text { 至尾端 }\end{array}$ & 頭部廣 & $\begin{array}{l}\text { 腸先端 } \\
\text { 部, 楌 }\end{array}$ & $\begin{array}{l}\text { 肛門部二於 } \\
\text { ケル體幅 }\end{array}$ & $\begin{array}{l}\text { 口毒原基 } \\
\text { アルモノ }\end{array}$ & \multicolumn{2}{|c|}{ 第一次卜ノ比較 } \\
\hline $\begin{array}{l}0.0142 \\
0.0076\end{array}$ & 0.084 & 0.0096 & 0.0115 & 0.0153 & ナ シ & \multicolumn{2}{|c|}{ 何等認ムベキ發育ナシ } \\
\hline $\begin{array}{l}0.0115 \\
0.0076\end{array}$ & 0.084 & 0.0115 & 0.0115 & 0.0153 & $ナ \quad シ$ & 同 & 上 \\
\hline $\begin{array}{l}0.0153 \\
0.0076\end{array}$ & 0.080 & 0.0115 & 0.0115 & 0.0153 & $ナ$ & 同 & 上 \\
\hline- & - & - & - & - & - & & \\
\hline $\begin{array}{l}0.0115 \\
0.0076\end{array}$ & 0.080 & 0.0115 & 0.0115 & 0.0153 & $ナ$ & \multicolumn{2}{|c|}{$\begin{array}{l}\text { 體內顆粒〉減少多ク一般二透 } \\
\text { 明 }\end{array}$} \\
\hline
\end{tabular}

\section{第二章 對照惯䛗}

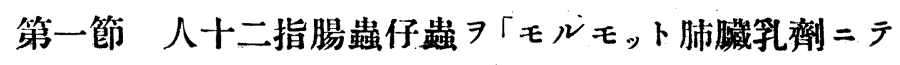

處置セル後家兔二與へシ場合ノ發育狀態

人十二指腸蟲仔蟲 テモルモ。卜肺臟乳劑（生理的食監水二テ作リシモノ）:中二入レ 2 時間攝氏 37 度, 躬卵器內二置キタル 後家鬼二與へ感染後 7 日目二撲殺シ 發育狀態 ヨ检セリ。仔蟲, 分布狀態八第 2 表 (其ノ一) 二示ス如クニテ氣管及ビ䐅頭胃二多っ見 出サレタリ。

仔蟲ノ發育狀態八第 2 表(其)二)二示ス如ク各主要藏器タル肺藏氣管及ビ喉頭. 胃. 小腸. 大腸等ヨリ得タル幼蟲ハ何レモ著明ナル發育的所見キ示スモノ八終ニ見出シ得 ザリキ。 
第 2 表（其ノ一）對照賽驗 被萝仔蟲及ビ「モルモット．人體．家鬼脯

\begin{tabular}{|c|c|c|c|c|c|c|c|c|c|}
\hline \multirow[b]{2}{*}{ 使用七シ仔蟲 } & \multicolumn{2}{|c|}{ 家＼cjkstart鬼 } & \multirow{2}{*}{$\begin{array}{l}\text { 感經 } \\
\text { 染過 } \\
\text { 日 } \\
\text { 後數 }\end{array}$} & \multirow{2}{*}{ 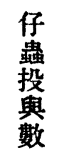 } & \multicolumn{2}{|c|}{ 檢 出 数 } & \multicolumn{2}{|c|}{ 肺 } & \multirow{2}{*}{ 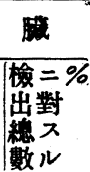 } \\
\hline & $\begin{array}{l}\text { 番 } \\
\text { 號 }\end{array}$ & 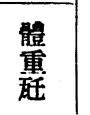 & & & 總 & 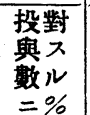 & 檢 & 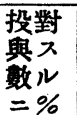 & \\
\hline 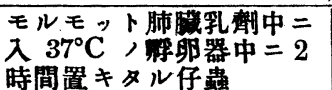 & 6 & 1.800 & 7日 & 4000 & 126 & 3.15 & 20 & 0.50 & 15.78 \\
\hline 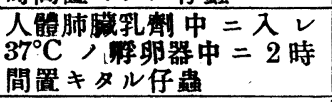 & 7 & 1.750 & 8日 & 2000 & 190 & 9.5 & 5 & 0.25 & 7.8 \\
\hline 上 & 8 & 2.100 & 13 日 & 5000 & 131 & 2.62 & 12 & 0.24 & 9.1 \\
\hline 培食後滿 5 日，仔蟲 & 9 & 1.900 & 11日 & 5000 & 603 & 12.06 & 41 & 0.82 & 6.7 \\
\hline 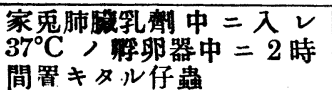 & 10 & 2.000 & 7日 & 4000 & 110 & 2.07 & 17 . & 0.42 & 15.4 \\
\hline
\end{tabular}

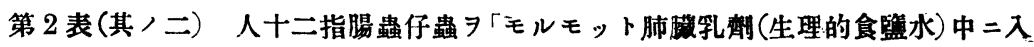

\begin{tabular}{|c|c|c|c|c|c|c|c|}
\hline & & 家鬼番號 & 玈過時間 & 體 長 & 體 幅 & 食道長 & 食道球幅 \\
\hline 肺 & 臓 & 6 & 7 日 & 0.669 & 0.0230 & 0.149 & 0.0153 \\
\hline 氣 管 及 ビ 喉 & 頭 & & & 0.697 & 0.0230 & 0.165 & 0.0153 \\
\hline \multicolumn{2}{|l|}{ 胃 } & & & 0.688 & $0.02 \Omega 6$ & 0.161 & 0.0153 \\
\hline \multirow{2}{*}{ 小 } & \multirow{2}{*}{ 腸 } & & & 大 0.714 & 0.0234 & 0.172 & 0.0153 \\
\hline & & & & 小0.647 & 0.0215 & 0.145 & 0.0134 \\
\hline 大 & 腸 & & & 0.655 & 0.0230 & 0.149 & 0.0153 \\
\hline
\end{tabular}

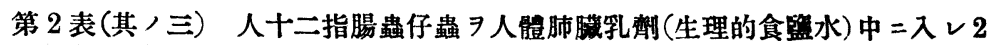

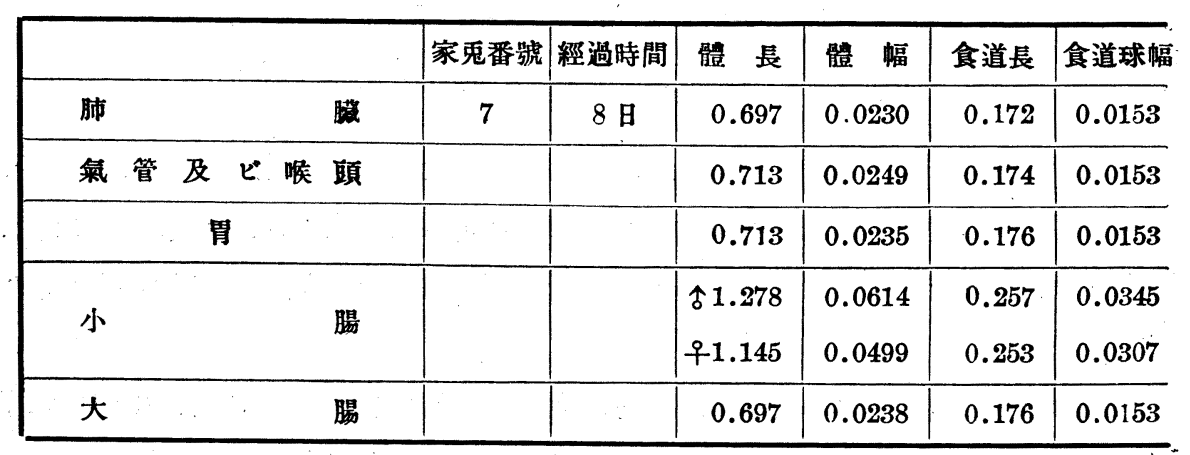

第二節 人十二指腸蟲仔蟲 $尹$ 人體肺臟乳劑二テ處置七 ル後家鬼二與へシ場合, 發有狀態 


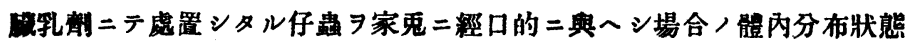

\begin{tabular}{|c|c|c|c|c|c|c|c|c|c|c|c|}
\hline \multicolumn{3}{|c|}{ 氣管及ビ喉頭 } & \multicolumn{3}{|c|}{ 胃 } & \multicolumn{2}{|c|}{ 小 } & 腸 & \multicolumn{2}{|c|}{ 大 } & \multirow{2}{*}{ 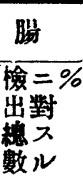 } \\
\hline 檢 & 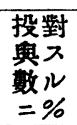 & 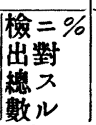 & 缹 & 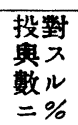 & 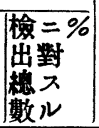 & 檢 & 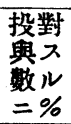 & 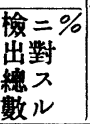 & 檢 & 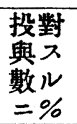 & \\
\hline 53 & 1.32 & 42.06 & 32 & 0.80 & 25.39 & 16 & 0.40 & 12.69 & 5 & 0.12 & 3.96 \\
\hline 108 & 5.40 & 56.84 & 29 & 1.45 & 15.26 & 44 & 2.20 & 83.15 & 4 & 0.20 & 2.10 \\
\hline 39 & 0.78 & 29.74 & 67 & 1.34 & 51.15 & 10 & 0.20 & 7.63 & 3 & 0.06 & 2.29 \\
\hline 360 & 7.20 & 59.70 & 128 & 2.56 & 21.22 & 65 & 1.30 & 10.77 & 9 & 0.18 & 1.49 \\
\hline 35 & 0.87 & 31.81 & 48 & 1.20 & 43.63 & 8 & 0.20 & 7.27 & 2 & 0.05 & 1.81 \\
\hline
\end{tabular}

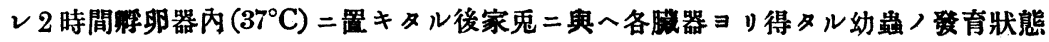

\begin{tabular}{|c|c|c|c|c|c|c|c|c|}
\hline $\begin{array}{l}\text { 生殖器 } \\
\text { 基 }\end{array}$ & $\begin{array}{l}\text { 自擝門 } \\
\text { 至尾端. }\end{array}$ & 頭部廣サ & $\begin{array}{l}\text { 腸先端 } \\
\text { 部, 鹿 }\end{array}$ & $\begin{array}{l}\text { 埾門部二於 } \\
\text { ケル體幅 }\end{array}$ & $\begin{array}{l}\text { 口嚄 } \\
P ル=\end{array}$ & 原基 & \multicolumn{2}{|c|}{ 第一次ト 比較 } \\
\hline $\begin{array}{l}0.0134 \\
0.0069\end{array}$ & 0.084 & 0.0096 & 0.0115 & 0.0145 & & ע & \multicolumn{2}{|c|}{ 著明ノ發育 ヨ認メズ } \\
\hline $\begin{array}{l}0.0115 \\
0.0076\end{array}$ & 0.080 & 0.0115 & 0.0115 & 0.0153 & ナ & シ & 同 & 上 \\
\hline $\begin{array}{l}0.0142 \\
0.0072\end{array}$ & 0.084 & 0.0115 & 0.0115 & 0.0153 & ナ & ע & 同 & 上 \\
\hline $\begin{array}{l}0.0153 \\
0.0076\end{array}$ & 0.088 & 0.0122 & 0.6115 & 0.0165 & 土 & ט & \multirow{2}{*}{\multicolumn{2}{|c|}{ 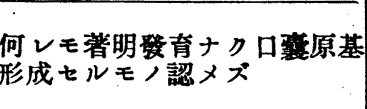 }} \\
\hline $\begin{array}{l}0.0115 \\
0.0065\end{array}$ & 0.080 & 0.0096 & 0.0096 & 0.0145 & 厂 & 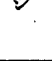 & & \\
\hline $\begin{array}{l}0.0115 \\
00076\end{array}$ & 0.080 & 0.0115 & 0.0096 & 0.0145 & ナ & シ & \multicolumn{2}{|c|}{ 墢育セルモノナシ } \\
\hline
\end{tabular}

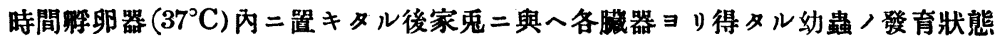

\begin{tabular}{|c|c|c|c|c|c|c|}
\hline $\begin{array}{l}\text { 生值器 } \\
\text { 基 }\end{array}$ & $\begin{array}{l}\text { 自沿門 } \\
\text { 至尾端 }\end{array}$ & 頭部／庴 & $\begin{array}{l}\text { 醐先端 } \\
\text { 部, 懬 }\end{array}$ & 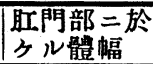 & 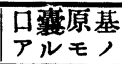 & 第一次卜 / 比較 \\
\hline $\begin{array}{l}0.0153 \\
0.0076\end{array}$ & 0.082 & 0.0115 & 0.0115 & 0.0153 & ナ & 著明ノ発育ナシ \\
\hline $\begin{array}{l}0.0192 \\
0.0076\end{array}$ & 0.084 & 0.0115 & 0.0115 & 0.0153 & ナ シ & 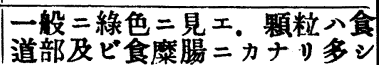 \\
\hline $\begin{array}{l}00153 \\
0.0076\end{array}$ & 0.084 & 0.0119 & 0.0115 & 0.0172 & シ & 著明ノ繁育 \\
\hline- & $\begin{array}{l}0.088 \\
0.088\end{array}$ & 0.0345 & $\begin{array}{l}0.0345 \\
0.0268\end{array}$ & $\begin{array}{l}0.0307 \\
0.0272\end{array}$ & $\frac{29}{4 \frac{9}{4}}$ & 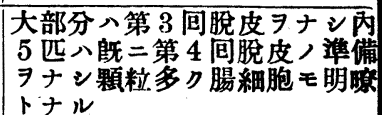 \\
\hline $\begin{array}{l}0.0115 \\
0.0076\end{array}$ & 0.084 & 0.0115 & 0.0096 & 0.0153 & ナ & 著明 ，發有ナシ \\
\hline
\end{tabular}

本實驗八既二第一編二於テ詳述七ル所ナルモ更二仔犬二感染セシメタル仔蟲ト同糞 便ヨリ培養シ得タル仔蛅テ用ヒタリ。實驗方法八前述ノ如ク「モルモっト」肺臟乳劑二 ヨル場合ト同漾ナリ。 


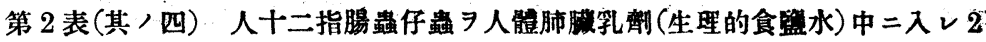

\begin{tabular}{|c|c|c|c|c|c|c|c|}
\hline & & $\mid$ 家鬼番號 $\mid$ & 橅過時間 $\mid$ & 體 長 & 體 幅 & 食道長 & 食道球幅 \\
\hline 肺 & 臟 & 8 & 13日 & 0.680 & 0.0230 & 0.168 & 0.0153 \\
\hline 氣管 及 ビ倨 & 頭 & & & 0.675 & 0.0230 & 0.162 & 0.0153 \\
\hline 胃 & & & & 0.737 & 0.0238 & 0.180 & 0.0153 \\
\hline 小 & 腸 & 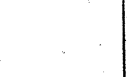 & & $\begin{array}{r}1.860 \\
\text { \$े1.245 }\end{array}$ & $\begin{array}{l}0.0806 \\
0.0614\end{array}$ & $\begin{array}{l}0.307 \\
0.257\end{array}$ & $\begin{array}{l}0.0460 \\
0.0307\end{array}$ \\
\hline 大 & 腸 & & & 0.647 & 0.0230 & 0.162 & 0.0145 \\
\hline
\end{tabular}

發育狀態き檢スル第 2 表 (其)三及ビ其，四)二示ス如ク肺臟. 氣管及ビ喉頭二於テ 八何等認ムべキ發育ナきモ。帠二於テハ少數ナルモ口露原基き形成シ發有セルモノタ

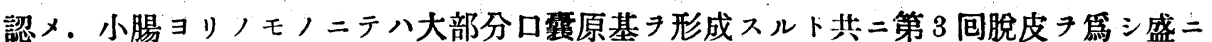

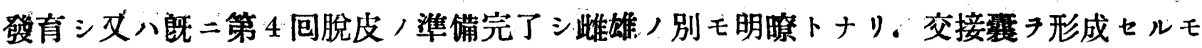
ノアリ．體長．體幅ハ著シク增大シ食様腸二於ケル顆粒ノ沈著モ極メテ多ク．腸壁細 胞等モ明暸トナリ。著シキ發育き示スモノ多キキ認メタリ。

大腸二於ケルモノ八之二反シ著明ノ發育認ムルモノナシ。

以上，如ク本實驗二於テモ又明カ二仔犬，肺臟通過後家鬼二與へタル場合二比シ顯 著ナル相違アルモノニシテ前記モルモ。ト肺藏乳劑/場合二比シ甚シキ發有的相違き 來スモノナルコトキ知レッ。

\section{第三節 人十二指腸蟲完熟仔蟲 7 何等/處置 $尹$ 加いズ}

\section{家鬼二與へタル場合ノ發育狀態}

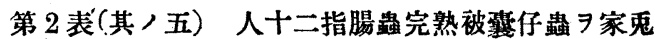

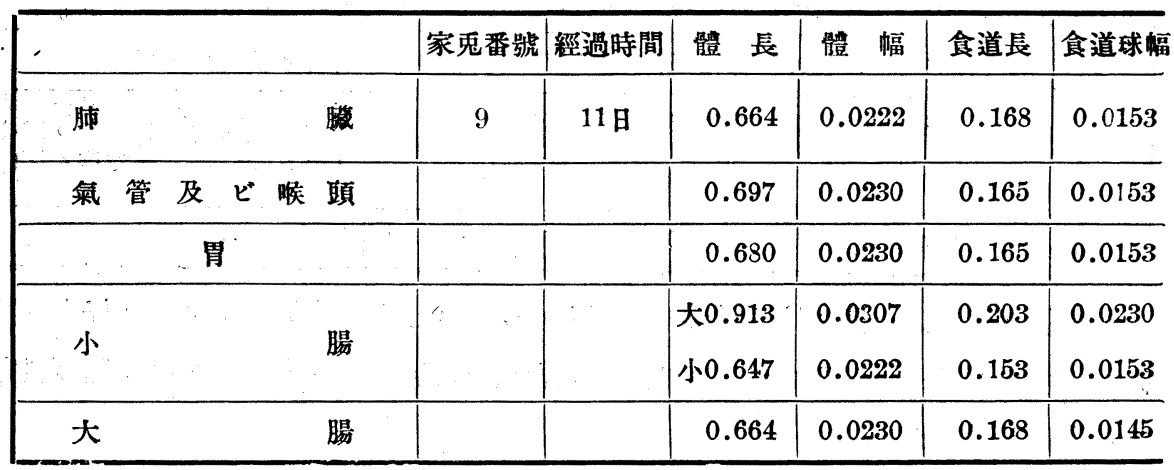




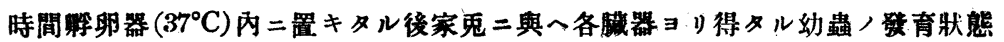

\begin{tabular}{|c|c|c|c|c|c|c|}
\hline $\begin{array}{l}\text { 生殖器 } \\
\text { 原基 }\end{array}$ & $\begin{array}{l}\text { 自胿門 } \\
\text { 至尾端 }\end{array}$ & 頭部 /廣 & $\begin{array}{l}\text { 腸先端 } \\
\text { 部，廣 }\end{array}$ & $\begin{array}{l}\text { 肞門部二於 } \\
\text { ケル體幅 }\end{array}$ & $\begin{array}{l}\text { 口糞原基 } \\
\text { アルモ⿰ }\end{array}$ & 第一次卜／比較 \\
\hline $\begin{array}{l}0.0153 \\
0.0076\end{array}$ & 0.080 & 0.0115 & 0.0115 & 0.0153 & $ナ \quad シ$ & 著明／登育ナシ \\
\hline $\begin{array}{l}0.0153 \\
0.0076\end{array}$ & 0.084 & 0.0115 & 0.0115 & 0.0153 & ナ シ & 同上 \\
\hline $\begin{array}{l}0.0153 \\
0.0076\end{array}$ & 0.086 & 0.0115 & 0.0115 & 0.0192 & $\frac{2}{67}$ & 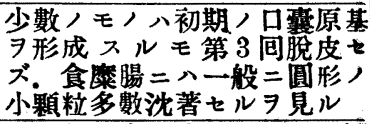 \\
\hline - & $0 . \overline{092}$ & $\begin{array}{l}0.0345 \\
0.0307\end{array}$ & $\begin{array}{l}0.0422 \\
0.0307\end{array}$ & $\begin{array}{l}0.0652 \\
0.0272\end{array}$ & $\frac{7}{10}$ & 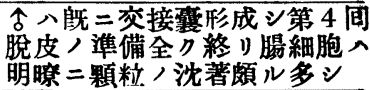 \\
\hline $\begin{array}{l}0.0145 \\
0.0076\end{array}$ & 0.080 & 0.0096 & 0.0115 & 0.0153 & ナ & 著明ノ慜厺 ア認メズ \\
\hline
\end{tabular}

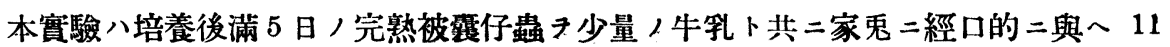

日目二撲殺シ检セリ。

仔蟲/發育狀態八第 2 表 (其, 五)二示ス如ク肺藏氣管. 胃ヨリ得タルもノ八何レモ 認ムベキ發有ナク僅カ二小腸ヨリ得タル幼蟲 65 匹中 1 匹二於テ第 3 回脫皮中，モ， アリシモ其他ハ何レモ著明ナル發有キ認ムルコトナク. 第一編二於テ述べタルト同樣 ナリキ。

第四節 人十二指腸蟲仔蟲 7 家鬼肺臟孚劑二テ處置七 ル後家鬼二與へタル場合ノ發育狀態

實驗方法八前述 人體肺㖑乳劑及ビ「モルモ。ト肺臟乳劑 ニ低レル場合ト同樣キ リ。

仔蟲ノ發育狀態八第 2 表(其ノ六)二示ス如ク各主要藏器ヨリ得タル奻蟲ハ何レモ著 明ノ發育き認ムル事ナク第一編二於テ行ヒタル賽驗ノ場合ト略了同樣ナリキ。

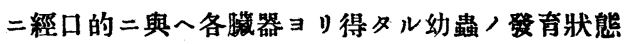

\begin{tabular}{|c|c|c|c|c|c|c|}
\hline 生殖器 & $\begin{array}{l}\text { 自肛門 } \\
\text { 至尾端 }\end{array}$ & 頭部 /廣 & $\begin{array}{l}\text { 腸先端 } \\
\text { 部, 懬 }\end{array}$ & $\begin{array}{l}\text { 肛門部二於 } \\
\text { クル體幅 }\end{array}$ & $\begin{array}{l}\text { 口蓒原基 } \\
\text { アルモノ }\end{array}$ & 第一次トノ比較 \\
\hline $\begin{array}{l}0.0115 \\
0.0076\end{array}$ & 0.080 & $0 . C 036$ & 0.0115 & 0.0153 & ナ シ & $\begin{array}{l}\text { 何等認么べキ發育ナク顆粒， } \\
\text { 減少シ飛白狀ヨ呈スルモモ } \\
\text { シ }\end{array}$ \\
\hline $\begin{array}{l}0.0145 \\
0.0076\end{array}$ & 0.084 & 0.0115 & 0.0115 & 0.0153 & ナ シ & 一般二透明二見工顆粒減少多 \\
\hline $\begin{array}{l}0.0115 \\
0.0076\end{array}$ & 0.080 & 0.0115 & .0 .0115 & 0.0153 & $\dot{H}$ & 著明ノ䏍 ヨ認メズ \\
\hline $\begin{array}{c}- \\
0.0115 \\
0.0076\end{array}$ & $\begin{array}{l}0.084 \\
0.078\end{array}$ & 0.0096 & $\begin{array}{l}0.0192 \\
0.0096\end{array}$ & $\begin{array}{l}0.0268 \\
0.0153\end{array}$ & $\frac{1}{65}$ & 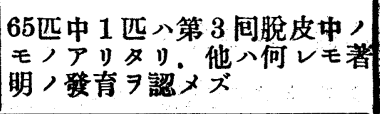 \\
\hline $\begin{array}{l}0.0115 \\
0.0076\end{array}$ & 0.080 & 0.0115 & 0.0115 & 0.0153 & $ナ$ & 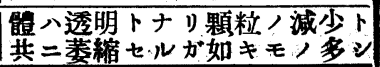 \\
\hline
\end{tabular}




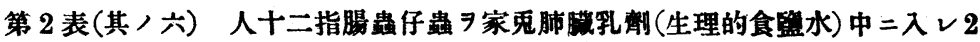

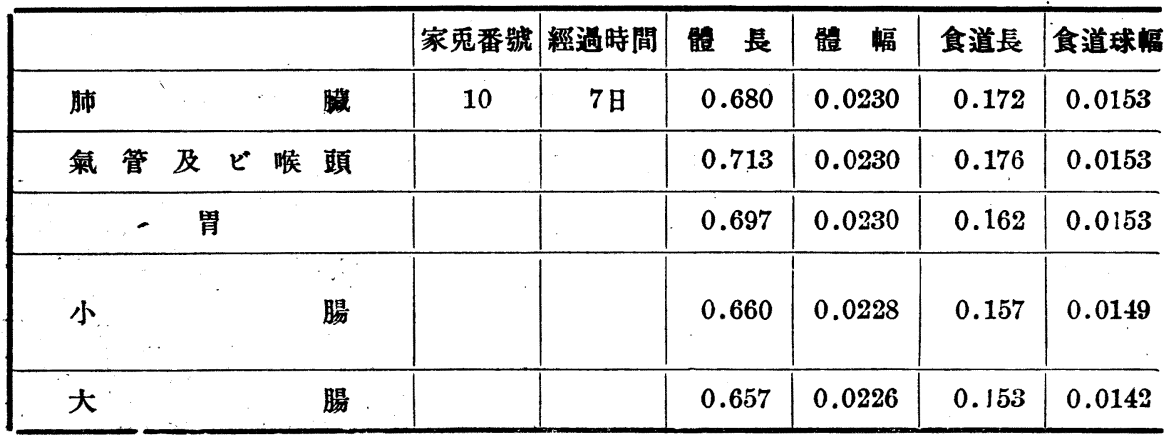

\section{第三 總括的所是}

以上述ベタル實驗成績 總括的二述ブレバ下ノ如シ。

人十二指腸蟲完熟仔蟲尹仔犬二經虞的二感染七シメ. 24 時間後ソ/肺臟ヨリ得タル 幼蟲更二家鬼二經口的二與へ各主要藏器ヨリ得タル幼蟲二就キ具ニソ/發有狀態ョ 檢スルニ感染後 3 日目ノモノニテ八. 何レノ藏器ヨリ得タルモノモ。發有ヨ示スモノ ナク・5日目ノモノニ於テモ又同樣發有セルモノナシ。 7 日目ノモノニテハ僅カニ小 腸ヨリ得タルモノニ八. 體長. 體幅少シク增大七ルモ初期ノ口哄原基形成七ルモノ ナク・他ニ八何等認ムベキ發育ナシ。9 日目ノモノニテ八肺藏. 氣管等ヨリ得タル幼 蟲二八著明ノ發育ナキモ胃中ヨリ見出セル仔蟲二口覆原基キ形成セルモノ僅カ二一隻

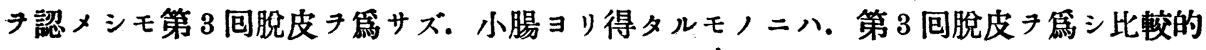
食糜腸二八多クノ顆柆沈著シ發育き示セルモノ又一隻アリ。他ノモノニ八著明ノ發育 ヨ認メズ。11 日目ノモノ八肺藏. 氣管. 胃等ヨリ得タル幼蟲ニハ大ナル發有ナク．唯

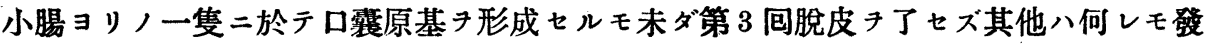
育七ルモノナカリキ。

對照實驗トシテ行へル。モルモット肺臟乳谚二テ處置セル場合. 端二家兔肺藏乳剂二 テ處置七バ昜合 八共二各主要藏器ヨリ得タル幼蟲ハ何レモ著明ノ發育ナク. 家鬼二

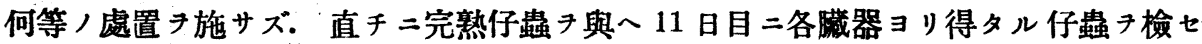
ルニ極メテ稀レナレドモ一隻第 3 回脫皮中ノモノアリタリ。是二反シ人體肺藏乳劑二 テ處置セル場合二於ケル實驗二八可成り著明/發有キ示スモ/多ク8 日目ノ小腸ヨリ 得タルモノ八大部分ハ口襄原基キ形成セルハ勿論. 第 3 回脫皮キナシヌハ既二第 4 回 脫皮ノ準供ナナシ. 體內顆粒モ增加シ. 感染後 13 日目ノモノニ於テ八同樣小腸二於 
時間等卵器 $\left(37^{\top} \mathrm{C}\right)$ 內二置キタル後家无二與へ各䑏器ヨリ得タル幼蟲ノ發育狀態

\begin{tabular}{|c|c|c|c|c|c|c|c|}
\hline $\begin{array}{l}\text { 告殖器 } \\
\text { 原基 }\end{array}$ & $\begin{array}{l}\text { 自肘門 } \\
\text { 至尾端 }\end{array}$ & 頭部／度 & $\begin{array}{l}\text { 晹先端 } \\
\text { 部,廣 }\end{array}$ & \begin{tabular}{|l} 
盯 $\left.\right|^{-1}$ 部二於 \\
ケル體幅
\end{tabular} & 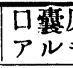 & モ原基 & 第一次卜，比較 \\
\hline $\begin{array}{l}0.0153 \\
0.0076\end{array}$ & 0.084 & 0.0115 & 0.0115 & 0.0153 & ナ & シ & 著明ノ發育 認メズ \\
\hline $\begin{array}{l}0.0153 \\
0.0076\end{array}$ & 0.086 & 0.0134 & 0.0126 & 0.0168 & $ナ$ & シ & 同上 \\
\hline $\begin{array}{l}0.0153 \\
0.0076\end{array}$ & 0.084 & 0.0115 & 0.0115 & 0.0153 & $ナ$ & シ & 同 \\
\hline $\begin{array}{l}0.0136 \\
0.0076\end{array}$ & 0.080 & 0.0115 & 0.0115 & 0.0153 & $ナ$ & シ & 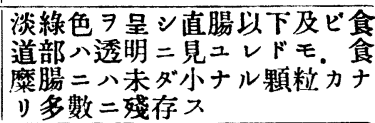 \\
\hline $\begin{array}{l}0.0115 \\
0.0076\end{array}$ & 0.080 & 0.0096 & 0.0115 & 0.0149 & $ナ$ & シ & 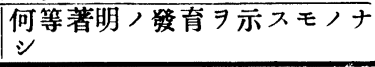 \\
\hline
\end{tabular}

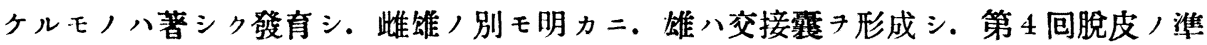

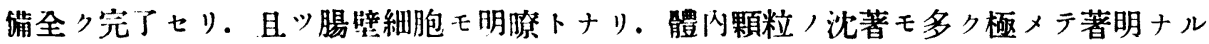
發育キ示スモノアリタリ。

\section{結 論}

1. 人十二指腸蟲 Anchylostoma duodenale, Dubini. 仔蟲子仔犬二經膚的二感染 セシメ.ソノ肺臟ヨリ得タル幼蟲キ家兔二與フルトモ通則トシテ八著明ノ發育キ遂グ ルモノナシ。

2. 人十二指腸蟲仔蟲头異種動物タル家鬼二感染七シメタル實驗二於テ. 豫メ仔蟲

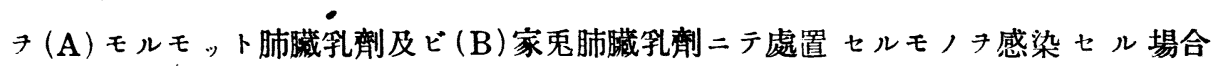

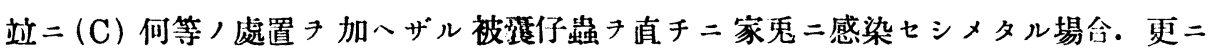

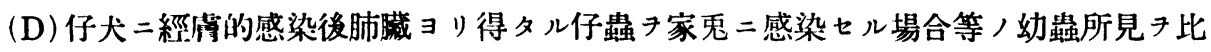
較スル:何レモ殆ンド發育キ認メザルキ通則トス。唯比較的ソ/發育二好影響丹與へ タルヤ二思ハル、ハ仔犬八肺臟き通過七ル仔蟲キ家鬼二感染七ル場合ナリキ。

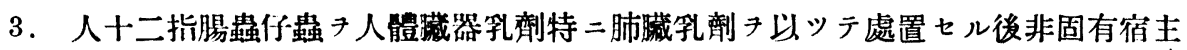
タル家鬼二與フル時ハ殆ンド常二極メテ顯著ナル發有キ遂グルノ事實キ認メタリ。

4. 以.上，實驗成績及锖二發表七几第一編，實驗所見ヨリシテ考察スルニ前述，如

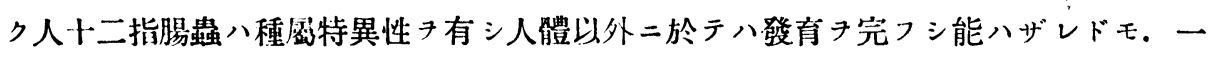

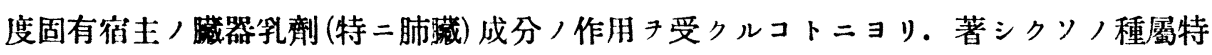

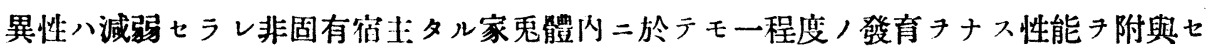
ラル、ノ事實ヨ確認シ得タリ然レドモ。非固有宿主タル「モルモット家鬼ノ肺臟乳劑 ニテ處置セルモ/及ビ仔犬／肺臟キ通過セルモノキ以ッテセル場合二於テハカ、ル所 
見キ認ムル事能ハザリキ。

弦二於テ余八更二人十二指腸蟲ノ發育二際シテ八固有宿主ノ體組織 (特二肺䑏) 成分 ，作用テ受ケテ始メテ將來一定度二發育シ得ル性能獲得スルモノニシテ十二指腸至 ノ感染二際シ仔蟲, 營ム肺诸環八誠二仔蟲ノ發育上緊要缺クベカラザルモノニシテ。 重大ナル生物學的意義丹有スルモノナリト思考ス。

擱筆スル二際シ所長. 長㠘教授二敬意キ表シ。終始御懇篤ナル御指導站二本稿御校 閱キ睗ハリタル恩師官川教授二滿腔ノ感謝ノ意キ捧グルモノナリ。

\section{文}

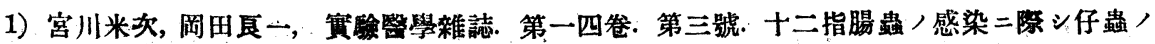

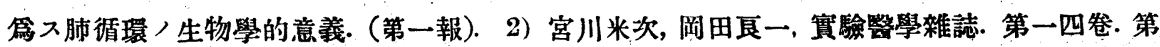
九號. 十二指腸蟲，感染二際 8 仔蟲，篇入肺循環，生物學的意義. (第二報). 3) 中島勝美,

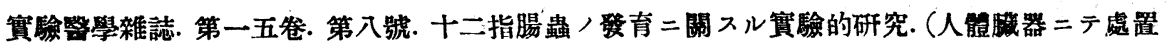
セラレタル人十二指腸蟲仔蟲，家鬼體內二於ヶル發育狀態二就テ). 第一編. 4) 中島勝美,

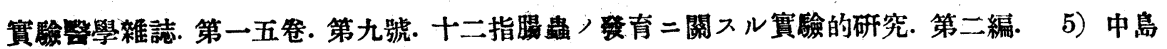
勝美, 實醫騟雜誌. 第一五卷. 第十號.十二指晹蟲/發育二關スル實驗的研究. 第三編.

\section{附回說明}

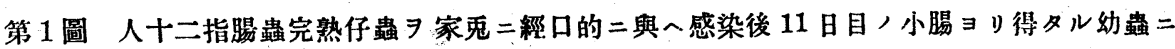

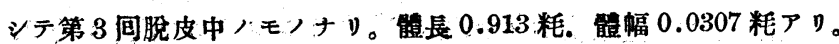

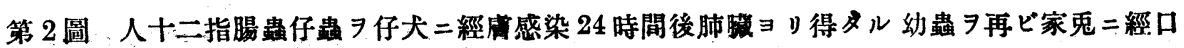

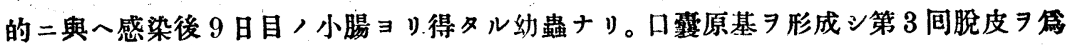
シ比較的發育セり。體長 0.996 䊗. 幅 0.0384 粍アリ。令

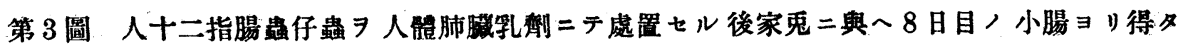
ル幼蟲ニシテ第 3 问脫皮 $\ni$ 篇シ體內顆粒，沈著モ多》腸細胞等モ漸次明暸トナり發 育大二進ミタリ。體長 1.012 籷. 體幅 0.0384 饿アリ。令

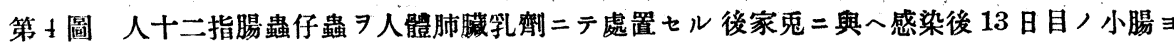

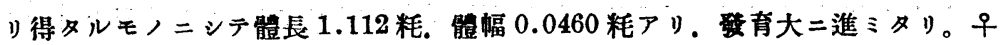

第 5 圖人十二指腸蟲仔䖵 7 人體肺滕乳劑 $=$ テ處置セル後家兔二經口的二與へ 13 日目八小腸 ヨリ得タル幻䩶ニシテ第 4 回脫皮ノ準備ヨナシ顆粒沈着著シク發育大二進ミタリ。體 .長 1.245 粍。體幅 0.0614 籷アリ。早

第 6 圖人十二指腸䖵仔䖵 7 人體肺臟乳劑二テ蟲置セル後家鬼二與へ 8 日目, 小腸 ヨリ得タ ルモノニシテ第 4 回脱皮ノ準備ヨナシ發充大二進ミタり。體長 1.278 粍、體幅 0.0614 粍厂リ。占

第 7 圖人十二指晹蟲仔蟲 $\ni 人$ 體肺臟乳劑二テ處置セル後家兔二與へ13 日目ノ小腸ヨリ得タ

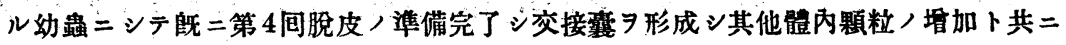

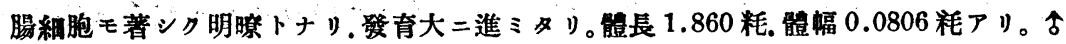


in

intoratise

The row

6]

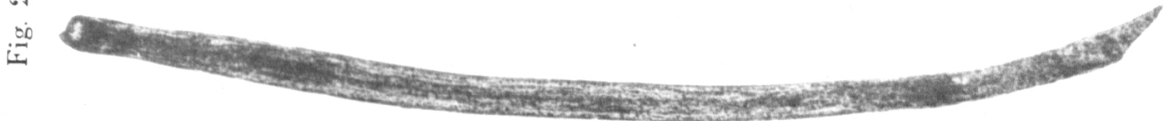

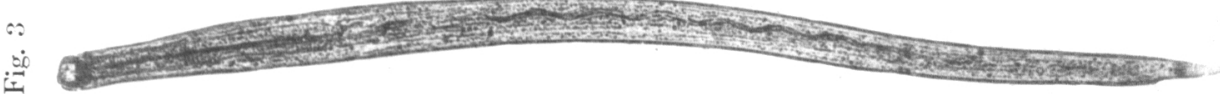

阳

窟

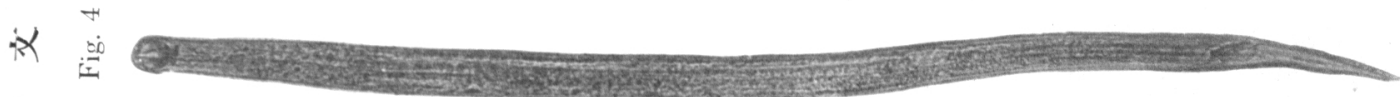

繶

园

$\div$

in $\begin{array}{ll}10 \\ \text { in }\end{array}$

in $i$ in

番 